SHORT REPORT

\title{
Plasma phenylalanine in patients with phenylketonuria self-managing their diet
}

\author{
J Bekhof, M van Rijn, P J J Sauer, E M Ten Vergert, D-J Reijngoud, F J van Spronsen
}

Arch Dis Child 2005;90:163-164. doi: 10.1136/adc.2003.040451

D ietary adherence in phenylketonuria (PKU)-measured by plasma phenylalanine (Phe) concentrations-is a major issue. ${ }^{12}$ In the so-called professionally steered situation, it was our practice to take all blood samples for measurement of Phe during patients' hospital visits. Phe concentrations were interpreted by the paediatrician, and the dietician phoned patients/parents with dietary advice. Selfmanagement has been suggested to improve dietary adherence. ${ }^{1}$ We report Phe concentrations during our first six months experiences with self-management in 48 PKU patients above 1 year of age.

During this period, patients decided frequency of blood sampling and sent samples (filter paper) to the laboratory by post. A nurse without knowledge of PKU phoned the results to patients/parents without interpretation/advice. Patients/parents decided independently regarding adjustments, but could phone the dietician for advice one day later. The clinical team received all blood test results weekly. When Phe concentrations were frequently deemed unsatisfactory, the dietician called the parent/ patient. During hospital visits (table 1), Phe concentrations, patients' adjustments, and use of protein substitute were evaluated.
Self-management was introduced following 1-2 individual meetings of patients with staff, two group sessions, and provision of written information, including advice regarding frequency of blood sampling, appropriate Phe concentrations (adapted from the British recommendations ${ }^{3}$ ), and dietary adjustments (table 1). As this was a change in management policy rather than a research study, there was no control group. Therefore, results of six months self-management (456 samples in 48 patients) (Wilcoxon test) were compared with those obtained over three years beforehand (1152 samples in 48 patients).

During self-management, most patients took blood samples according to the recommended frequency. The Phe intake changed in 10 patients (mean change $2.3 \%$, SD $5.7 \%$ ). The largest differences in intake were $32 \%$ and $16 \%$ of the total Phe daily given in $\mathrm{mg} /$ day, observed in two patients with changes in growth velocity during puberty.

Parents and professionals adjusted the diet in a comparable way. The dietician was phoned by families once or twice a week, while she phoned them twice a month. In patients aged 1-4 years and 11-15 years the Phe concentrations rose (table 2). The median proportion of samples within the advised range remained comparable, largely because of the

Table 1 Advised ranges for plasma Phe concentration and frequency for follow up

\begin{tabular}{|c|c|c|c|c|c|c|}
\hline \multirow[b]{2}{*}{ Age $(y)$} & \multicolumn{2}{|c|}{ Plasma Phe $(\mu \mathrm{mol} / \mathrm{l})$} & \multicolumn{2}{|c|}{ Blood sampling } & \multicolumn{2}{|c|}{ Clinical follow up } \\
\hline & Old & New & Old & New & Old & New \\
\hline $\begin{array}{l}\text { First year } \\
1-4 \\
5-10 \\
11-15 \\
>15\end{array}$ & $\begin{array}{l}120-240 \\
200-500 \\
200-500 \\
200-500 \\
200-500\end{array}$ & $\begin{array}{l}120-240 \\
120-360 \\
120-480 \\
120-480 \\
120-600\end{array}$ & $\begin{array}{l}\text { Fortnightly } \\
\text { Monthly } \\
\text { Every 6-8 wk } \\
\text { Every 6-8 wk } \\
\text { Every 3 mth }\end{array}$ & $\begin{array}{l}\text { Weekly } \\
\text { Weekly } \\
\text { Fortnightly } \\
\text { Monthly } \\
\text { Monthly }\end{array}$ & $\begin{array}{l}\text { Fortnightly } \\
\text { Monthly } \\
\text { Every 6-8 wk } \\
\text { Every 6-8 wk } \\
\text { Every } 3 \mathrm{mth}\end{array}$ & $\begin{array}{l}\text { Every 1-2 mth } \\
\text { Every } 2-3 \mathrm{mth} \\
\text { Every } 3-4 \mathrm{mth} \\
\text { Every half year } \\
\text { Every year }\end{array}$ \\
\hline
\end{tabular}

Old refers to the situation steered by professionals. New refers to the situation of self-management.

Table 2 Plasma phenylalanine concentration and proportion of samples with plasma phenylalanine above the recommended range in the situation steered by professionals and self-management

\begin{tabular}{|c|c|c|c|c|c|c|}
\hline \multirow[b]{2}{*}{ Age (y) } & \multicolumn{3}{|c|}{ Mean plasma phenylalanine $(\mu \mathrm{mol} / \mathrm{l})$ during situation } & \multicolumn{3}{|c|}{$\begin{array}{l}\text { Percentage samples with Phe above recommended range } \\
\text { during situation }\end{array}$} \\
\hline & $\begin{array}{l}\text { Steered by } \\
\text { professionals }\end{array}$ & Self-management & p value ${ }^{*}$ & $\begin{array}{l}\text { Steered by } \\
\text { professionals }\end{array}$ & Self-management & p value* \\
\hline $1-4(n=11)$ & 214 (183-995) & $327(189-1007)$ & 0.010 & $75(8-100)$ & 75 (14-95) & 0.929 \\
\hline $5-10(n=12)$ & $309(186-1414)$ & $326(208-1282)$ & 0.480 & $44(0-100)$ & $68(8-100)$ & 0.919 \\
\hline $11-15(n=14)$ & $315(155-433)$ & 392 (277-582) & 0.011 & $100(50-100)$ & $100(34-100)$ & 0.483 \\
\hline$>15(n=11)$ & $587(290-960)$ & $649(337-1266)$ & 0.068 & $67(0-100)$ & $50(0-100)$ & 0.075 \\
\hline All ages $(n=48)$ & $320(337-1266)$ & $382(189-1282)$ & $<0.001$ & $78(0-100)$ & $75(0-100)$ & 0.248 \\
\hline
\end{tabular}


decrease in frequency of Phe concentrations below the target range.

Various explanations can be given for the increase in Phe concentrations during self-management, including the normal rise with age, ${ }^{2}$ increased frequency of blood sampling, a tendency for patients to attempt a dietary intake compatible with Phe concentrations just below the advised upper limit, and sampling after an overnight fast rather than later in the day during the professionally steered situation.

The question whether this rise in Phe concentrations is important is hard to answer. The mean of the medians in 1-4 year old patients rose from 214 to $327 \mu \mathrm{mol} / \mathrm{l}$, but remained lower than most reported experiences. ${ }^{2}$ Younger patients are more vulnerable to higher Phe concentrations, but the importance of variable time periods of Phe concentrations far below $360 \mu \mathrm{mol} / \mathrm{l}$ below 10 years of age is uncertain. ${ }^{4-6}$

In conclusion, this first study on the effect of selfmanagement on plasma Phe concentrations in PKU has shown that self-management is a viable option, but further investigation of the effects and safety is warranted.

\section{ACKNOWLEDGEMENTS}

The authors wish to thank Theo van Dijk for establishing a method to measure the phenylalanine concentration in blood spots.
Authors' affiliations

J Bekhof, Isala klinieken, Locatie Sophia

M van Rijn, P J J Sauer, E M T Vergert, D-J Reijngoud, F J van

Spronsen, Groningen University, Netherlands

Competing interests: none declared

Correspondence to: Dr F J van Spronsen, Groningen University, Beatrix Children's University Hospital, PO Box 30.001, Groningen 9700 RB, Netherlands; f.j.van.spronsen@bkk.azg.nl

Accepted 10 June 2004

\section{REFERENCES}

1 Wendel U, Langenbeck U. Towards self-monitoring and self-treatment in phenylketonuria-a way to better diet compliance. Eur J Pediatr 1996;155(suppl 1):105-7.

2 Walter JH, White FJ, Hall SK, et al. How practical are recommendations for dietary control in phenylketonuria? Lancet 2002;360:55-7.

3 Medical Research Council. Recommendations on the dietary management of phenylketonuria. Arch Dis Child 1993;68:425-7.

4 Smith I, Beasly MG, Ades AE. Intelligence and quality of dietary treatment in phenylketonuria. Arch Dis Child 1990;65:472-8.

5 Stemerdink BA, van der Molen MW, Kalverboer AF, et al. Prefrontal lobe dysfunction in early and continuously treated phenylketonuria. Dev Neuropsychol 1999;16:29-57.

6 Huijbregts SCJ, De Sonneville LMJ, Van Spronsen FJ, et al. Executive motor control under lower and higher controlled processing demands in early- and continuously treated phenylketonuria. Neuropsychology 2003;17:360-79.

\section{IMAGES IN PAEDIATRICS}

First day back at school: an unusual presentation of a foreign body in the mouth

A distressed 8 year old child presented to the emergency department with part of a pencil sharpener firmly attached to the tip of her tongue. The small opening at the base of the aluminium globe had acted as a constricting ring, causing the tip of the tongue to swell and fill the contents of the globe. Although baseline observations were normal, the patient was unable to swallow effectively and was only able to breathe through her nose.

Using a small circular saw the globe was removed and following administration of dexamethasone and diclofenac, the patient was discharged the following day.
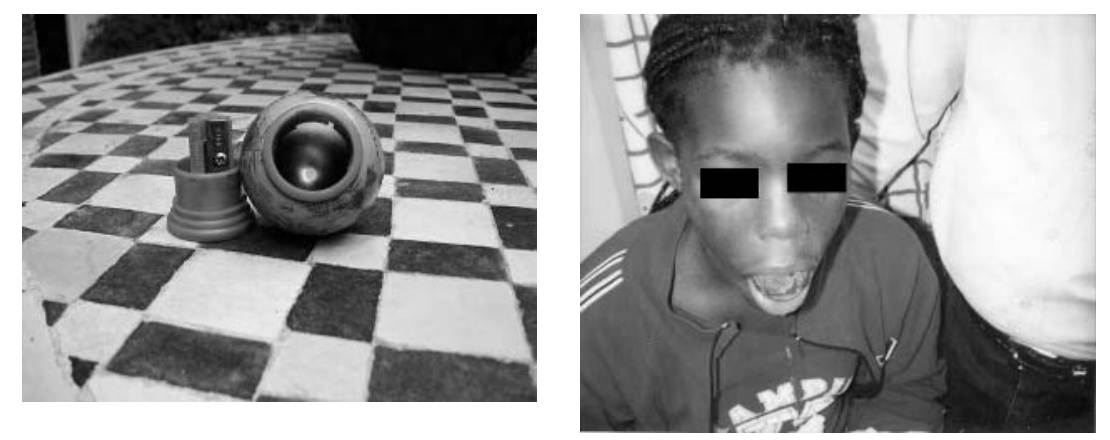

J Windsor, I Hore, J Fong, S McGuinness University College London Hospital, London, UK; jswindsor@doctors.org.uk 